\title{
Description of three new species of Potamonautes MacLeay, 1838 from the Lake Victoria region in southern Uganda, East Africa (Brachyura: Potamoidea: Potamonautidae)
}

\author{
Neil CUMBERLIDGE ${ }^{1, *} \&$ Paul F. CLARK ${ }^{2}$ \\ ${ }^{1}$ Northern Michigan University, Biology, 1401 Presque Isle Avenue, \\ Departe Marquette, Michigan 49855, USA. \\ ${ }^{2}$ Department of Life Sciences, Natural History Museum, Cromwell Road, \\ London SW7 5BD, UK. \\ *Corresponding author: ncumberl@nmu.edu \\ 2Email: p.clark@nhm.ac.uk \\ ${ }^{1}$ urn:1sid:zoobank.org:author:05F6365E-D168-4AE3-B511-80FA7E31ACC1 \\ ${ }^{2}$ urn:1sid:zoobank.org:author:BB4A2E90-621A-40BB-A90C-FFDCEE71A4E9
}

Cumberlidge N. \& Clark P.F. 2017. Description of three new species of Potamonautes MacLeay, 1838 from the Lake Victoria region in southern Uganda, East Africa (Brachyura: Potamoidea: Potamonautidae). European Journal of Taxonomy 371: 1-19. https://doi.org/10.5852/ejt.2017.371

\begin{abstract}
Three new species of potamonautid freshwater crabs are described from the Lake Victoria region in southern Uganda, East Africa. Two of the new species (Potamonautes busungwe sp. nov. and $P$. entebbe sp. nov.) are from the shores of Lake Victoria, while the third (P. kantsyore sp. nov.) is from an inland locality on the Kagera River that flows into the lake. In addition, two of the new taxa (P. busungwe sp. nov. and P. kantsyore sp. nov.) are among the smallest species of freshwater crabs so far known from Africa. Diagnoses, illustrations and distribution maps are provided for these taxa, which are compared to similar species from Uganda and elsewhere in East Africa.
\end{abstract}

Keywords. Potamonautes busungwe sp. nov., Potamonautes kantsyore sp. nov., Potamonautes entebbe sp. nov., Lake Victoria, Kagera River.

\section{Introduction}

This work focuses on a previously unreported collection of freshwater crabs from three different localities in southern Uganda that are all associated with Lake Victoria. The new species were collected during surveys of Uganda's wetland fauna between 1955 and 1967 that were aimed at gaining a better understanding of the role played by freshwater crabs in the transmission of river blindness (onchocerciasis) to humans (Barnley \& Prentice 1958; Williams et al. 1964; Williams 1968, 1991; Crosskey 1990). Although none of the crabs from this part of Uganda have been linked to river blindness, this material proved to include three new species, which are each described herein based on the adult male's possession of a unique combination of characters concerning the first gonopod, carapace, thoracic sternum and major cheliped. 
Recent taxonomic papers have described several new species of freshwater crabs from Uganda and it is becoming clear that the fauna in this country is much more diverse than previously thought (Table 1). The taxonomic history of the freshwater crabs of Uganda from 1837 until the present is discussed in detail and summarized in Tables 1-2. There was a gap of 52 years (1942 until 2001) when no new species of freshwater crabs were described from Uganda. Interest in this fauna resumed in the $21^{\text {st }}$ century when Corace et al. (2001) described a new species from the crater lake region of western Uganda, Cumberlidge \& Clark (2010a) described two new species from Mount Elgon in southeast Uganda, and Cumberlidge \& Clark (2016) described another two new species from the highlands of northern Uganda. In addition, Cumberlidge \& Clark (2010b, 2016) confirmed the validity of two other Ugandan species (Potamonautes loveni Colosi, 1924 and P. amalerensis Rathbun, 1935, respectively) and redescribed each of them based on the types and on previously unidentified museum material. Finally, Cumberlidge (2009) and Cumberlidge \& Clark (2010b) expanded the distributional range of P. niloticus (H. Milne Edwards, 1837) to include the entire Nile River drainage, and confirmed the presence of Sudanonautes floweri (De Man, 1901) in northwest Uganda. The present addition of three new species raises to 14 the number of freshwater crabs now known from Uganda (Bott 1955; Corace et al. 2001; Cumberlidge 2009; Cumberlidge \& Clark 2010a, 2010b, 2016).

All three of the new species of freshwater crabs described here belong to Potamonautes MacLeay, 1838, and the type material of each taxon is deposited in the National History Museum, London, UK (NHMUK). Unfortunately, molecular data for all three new species are not available because the material was originally preserved in formalin at the time of collection, up to 60 years ago. Diagnoses, illustrations and distribution maps are provided for these taxa, which are compared to similar species in the genus from the region.

\section{Material and methods}

Measurements were made with digital calipers and are given in millimeters $(\mathrm{mm})$. The terminology is adapted from Cumberlidge (1999) and the higher classification used here follows that of $\mathrm{Ng}$ et al. (2008). The habitus and gonopod photographs were taken with a digital camera in combination with a Leitz MZ 95 adapter and postprocessing was undertaken using Adobe Photoshop CC5. Adult females have an enlarged pleon that covers the coxae of the chelipeds and walking legs, possess broad feathery pleopods, and may or may not be carrying eggs or hatchlings in the abdominal brood pouch. The adults of freshwater crabs continue to grow after they reach sexual maturity (the moult of puberty) until the species attains its terminal moult. The beginning of the adult size range is indicated by female specimens with a CW equal to or greater than the CW of the smallest known adult female (Cumberlidge 1999; Cumberlidge et al. 1999; Marijnissen et al. 2004). This value for females was used here to establish the beginning of the adult size range for male specimens. The general lack of specimens for study means that there continues to be a need for more collections, so that the size range and the geographical distributional range of each species can be established with greater accuracy.

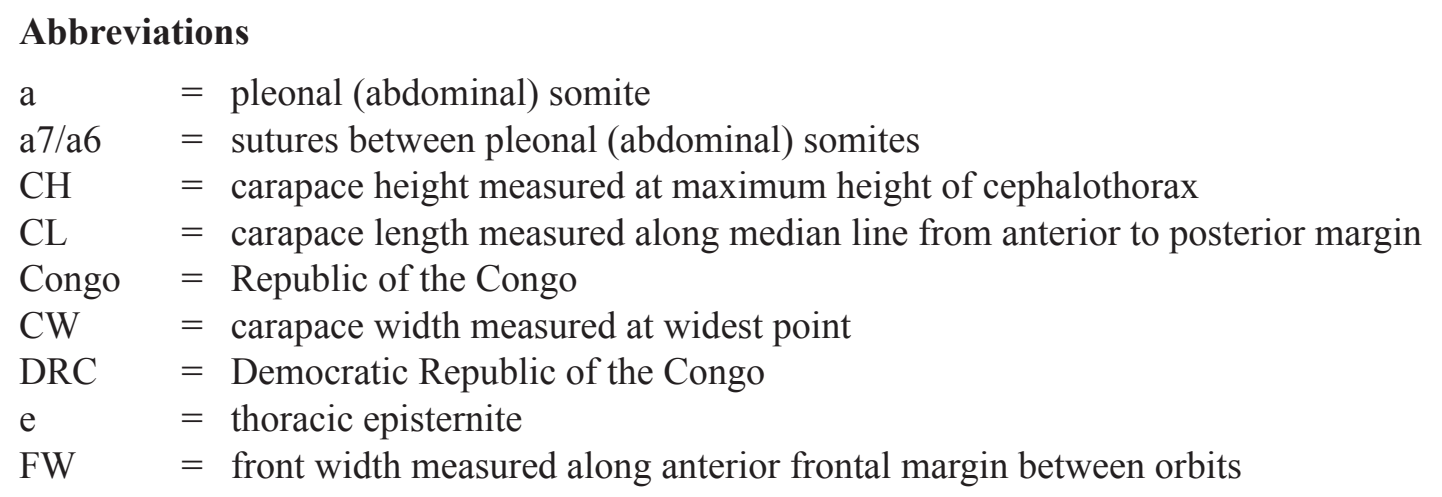


Table 1. Updated species list for Uganda recognized in the present work with the updated geographical distribution by country.

\begin{tabular}{|c|c|}
\hline Species & Distribution in present work \\
\hline Potamonautes niloticus (H. Milne Edwards, 1837) & Egypt, Sudan, Ethiopia, Uganda, Rwanda, Kenya \\
\hline Sudanonautes floweri (De Man, 1901) & $\begin{array}{c}\text { Nigeria, Cameroon, Equatorial Guinea (Bioko), } \\
\text { Central African Republic, Sudan, DRC, Congo, Gabon, } \\
\text { Angola (Cabinda), Uganda }\end{array}$ \\
\hline Potamonautes aloysiisabaudiae (Nobili, 1906) & DRC, Uganda \\
\hline Potamonautes loveni (Colosi, 1924) & Uganda, Kenya \\
\hline Potamonautes amalerensis (Rathbun, 1935) & Endemic to Uganda \\
\hline Potamonautes mutandensis (Chace, 1942) & Endemic to Uganda \\
\hline Potamonautes rukwanzi Corace, Garms \& Cumberlidge, 2001 & Endemic to Uganda \\
\hline Potamonautes elgonensis Cumberlidge \& Clark, 2010a & Endemic to Uganda \\
\hline Potamonautes williamsi Cumberlidge \& Clark, 2010a & Endemic to Uganda \\
\hline Potamonautes imatongensis Cumberlidge \& Clark, 2016 & Endemic to Uganda \\
\hline Potamonautes morotoensis Cumberlidge \& Clark, 2016 & Endemic to Uganda \\
\hline Potamonautes entebbe sp. nov. & Endemic to Uganda \\
\hline Potamonautes busungwe sp. nov. & Endemic to Uganda \\
\hline Potamonautes kantsyore sp. nov. & Endemic to Uganda \\
\hline
\end{tabular}

Table 2. Changes in the taxonomic treatment of Ugandan species of freshwater crabs that affect the status of the six species recognized by Bott (1955) vs their taxonomic status in the present work.

\begin{tabular}{|c|c|c|}
\hline Species & Distribution in Bott (1955) & Distribution in present work \\
\hline $\begin{array}{l}\text { Potamonautes niloticus (H. Milne } \\
\text { Edwards, 1837) }\end{array}$ & Egypt, Sudan, Ethiopia, Uganda & $\begin{array}{c}\text { Egypt, Sudan, Ethiopia, Uganda, } \\
\text { Rwanda, Kenya }\end{array}$ \\
\hline $\begin{array}{l}\text { Potamonautes aloysiisabaudiae } \\
\text { (Nobili, 1906) }\end{array}$ & $\begin{array}{c}\text { DRC, Uganda (with P. antheus } \\
\text { (Colosi, 1920) (Ethiopia) and } \\
\text { P. congoensis (Rathbun, 1921) (DRC) } \\
\text { as junior synonyms) }\end{array}$ & $\begin{array}{l}\text { DRC, Uganda (but with both } \\
P . \text { antheus and } P \text {. congoensis } \\
\text { removed from synonymy and } \\
\text { recognized as valid species) }\end{array}$ \\
\hline Potamonautes granviki (Colosi, 1924) & Uganda, Kenya & $\begin{array}{c}\text { Uganda, Kenya (but as } P \text {. loveni } \\
\text { with } P \text {. granviki treated as a } \\
\text { junior synonym) }\end{array}$ \\
\hline Potamonautes berardi (Audouin, 1826) & Egypt, Sudan, Ethiopia, Uganda & $\begin{array}{c}\text { Egypt, Sudan, Ethiopia (not Uganda } \\
\text { when misidentified specimens } \\
\text { are removed) }\end{array}$ \\
\hline Potamonautes emini (Hilgendorf, 1892) & $\begin{array}{l}\text { Tanzania, Uganda (P. mutandensis } \\
\text { treated as a junior synonym) }\end{array}$ & $\begin{array}{l}\text { Tanzania (not Uganda, because } \\
\text { P. mutandensis is a valid species) }\end{array}$ \\
\hline Potamonautes didieri (Rathbun, 1904) & $\begin{array}{l}\text { DRC, Uganda (with } P \text {. amalerensis } \\
\text { (Uganda) as a junior synonym) }\end{array}$ & $\begin{array}{l}\text { Uncertain, possibly DRC, Ethiopia } \\
\text { (not Uganda, because } P \text {. amalerensis } \\
\text { was removed from synonymy and } \\
\text { recognized as a valid species) }\end{array}$ \\
\hline
\end{tabular}




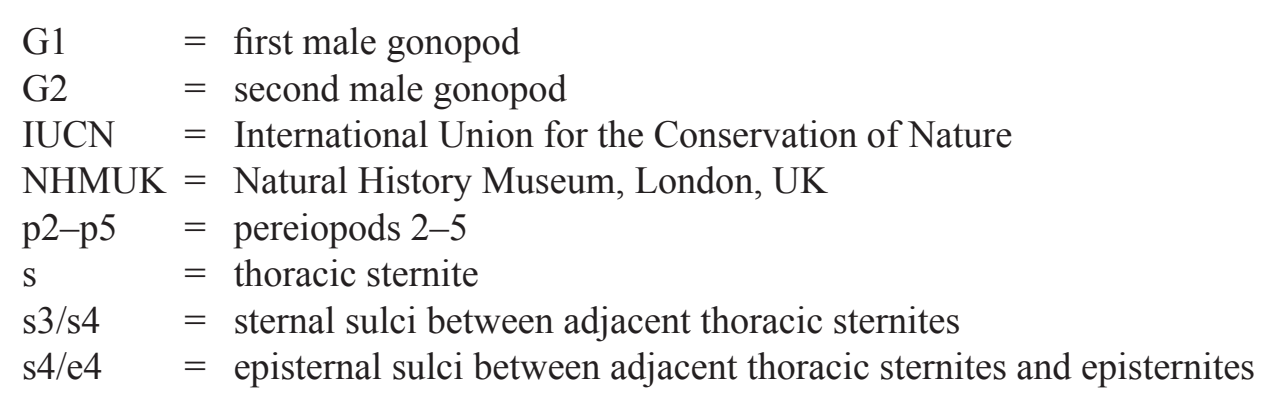

\section{Results}

\section{Diagnosis}

Infraorder Brachyura Latreille, 1802

Superfamily Potamoidea Ortmann, 1896

Family Potamonautidae Bott, 1970

Subfamily Potamonautinae Bott, 1970

Genus Potamonautes MacLeay, 1838

Potamonautes entebbe sp. nov.

urn:1sid:zoobank.org:act:566C13F5-AE87-4E75-8118-704C6F081488

Figs 1A-B, 4A, 5A-B, 6A, D, 7; Table 1

Postfrontal crest faint but complete, lateral ends meeting anterolateral margins at epibranchial teeth; exorbital, epibranchial teeth each reduced to granule; anterolateral margin posterior to epibranchial tooth smooth (Figs 1A, 4A). Third maxilliped ischium lacking vertical sulcus (Figs 1B, 4A); s3/s4 V-shaped, deep at sides, faint in middle; margins of s4 distinctly raised, thickened (Fig. 1B). Propodus, dactylus of major cheliped of adult male slim, elongated, both lined by small teeth, dactylus highly arched, enclosing oval interspace when closed (Figs 1A-B). Cheliped carpus inner margin distal tooth large, pointed, proximal tooth small, broad, pointed (Figs 1B, 5A-B). G1 terminal article short $(0.25 \times$ length of G1), slim, straight, curving gently outward, needle-shaped, evenly tapering, tip straight (Fig. 6A).

\section{Etymology}

The new species is named for the city of Entebbe, Uganda, which lies on the northern shore of Lake Victoria where this species was first collected. The specific epithet is used as a noun in apposition. Vernacular name: the Entebbe crab.

\section{Material examined}

Holotype (here designated)

UGANDA: adult ${ }^{\lambda}$, CW 35.0, CL 23.2, CH 11.6, FW $9.4 \mathrm{~mm}$, Entebbe, N shore of Lake Victoria, $1.04216^{\circ} \mathrm{N}, 30.67056^{\circ}$ E, 11 Aug. 1955, Captain C.R.S. Pittman leg. (NHMUK 1955.11.8.26).

\section{Paratype}

UGANDA: subadult + , CW $8.5 \mathrm{~mm}$, same collection data as for holotype (NHMUK 1955.11.8.27).

\section{Description}

Based on holotype (adult male CW $35 \mathrm{~mm}$ ). Carapace outline transversely oval, inflated (CH/FW 1.24; Fig. 1A), front broad measuring one-third CW (FW/CW 0.27; Fig. 4A). Postfrontal crest faint but complete, lateral ends meeting epibranchial teeth; epigastric crests distinct, median sulcus between crests short, forked posteriorly; semi-circular, urogastric, cardiac, posterior and cervical carapace grooves all faint. Exorbital tooth very low, blunt, epibranchial tooth reduced to granule; anterolateral 
margin between exorbital, epibranchial teeth smooth, lacking intermediate tooth, anterolateral margin posterior to epibranchial tooth smooth (Fig. 1A). Suborbital margin granular (Fig. 4A). Carapace sidewall vertical sulcus faint, incomplete, meeting longitudinal sulcus, dividing sidewall into three parts. Third maxilliped exopod with long flagellum, ischium lacking vertical sulcus (Fig. 4A). Epistomial tooth large, triangular, edges lined by granules (Fig. 4A). Mandibular palp 2-segmented; terminal segment simple; s2/s3 deep, running horizontally across sternum; s3/s4 V-shaped, deep at sides, faint in middle; margins of s4 distinctly raised, thickened (Fig. 1B); s4/e4, s5/e5, s6/e6 and s7/e7 all visible (Fig. 1B). Chelipeds of adult male unequal; fixed finger (propodus) and movable finger (dactylus) of major cheliped slim, elongated, both lined by small teeth, moveable finger highly arched, encompassing oval interspace when closed (Fig. 5A-B). Two pointed teeth on inner margin of cheliped carpus, distal tooth of medium size, proximal tooth small (Fig. 1A). Inferior margins of merus of cheliped with series of small sharp teeth, distal tooth pointed; superior surface of merus with carinae (Fig. 1 A-B). Pleon outline broadly triangular, with straight edges (Fig. 1B). G1 terminal article short $(0.25 \times$ length of G1), curving gently outward, broad at base, tapering evenly to straight tip (Fig. 6 A, D). G2 terminal article long $(0.5 \times$ length of $\mathrm{G} 2)$, flagellum-like.

Size. Medium-sized species, adult at CW $35 \mathrm{~mm}$.

CoLouR. Preserved specimens uniformly light brown.

\section{Distribution}

This species is known only from two specimens collected from a single locality at Entebbe, Uganda in the Lake Victoria drainage basin (Fig. 7). Although only sparse details of the habitat were provided by the collector, the inference is that this species was either collected on the Lake Victoria shoreline itself, or in a stream or river close to where it joins the lake.

\section{Ecology}

Little is known about the ecology of this species. Potamonautes entebbe sp. nov. is not found in a protected area and was collected from a locality that is either in or near Lake Victoria, adjacent to the city of Entebbe. At the time the specimens were collected (1955) this area was relatively undisturbed, but it is now under increasing pressure from anthropogenic pollution and disturbance.

\section{Conservation status}

An IUCN extinction risk assessment of $P$. entebbe sp. nov. has not yet been carried out, but given the fact that this species is known for only two specimens from a single locality, it would probably be regarded as Data Deficient.

\section{Remarks}

Potamonautes entebbe sp. nov. is superficially similar to several other species in this genus from Uganda that all share the following characters: a medium body size at maturity ( $\mathrm{CW} 30 \mathrm{~mm}$ and above); a complete postfrontal crest; reduced or absent exorbital and epibranchial teeth; a smooth anterolateral margin behind the epibranchial tooth; and a male major cheliped with a slim, elongated, highly arched dactylus. Ugandan crabs that share this suite of characters include four species from southeastern Uganda (P. loveni (Colosi, 1924), P. elgonensis Cumberlidge \& Clark, 2010, P. williamsi (Cumberlidge \& Clark, 2010) and P. amalerensis (Rathbun, 1935)), two from northern Uganda (P. morotoensis Cumberlidge \& Clark, 2016, and P. imatongensis Cumberlidge \& Clark, 2016), and two from western Uganda (P. aloysiisabaudiae (Nobili, 1906) and P. rukwanzi Corace, Cumberlidge \& Garms, 2001). 

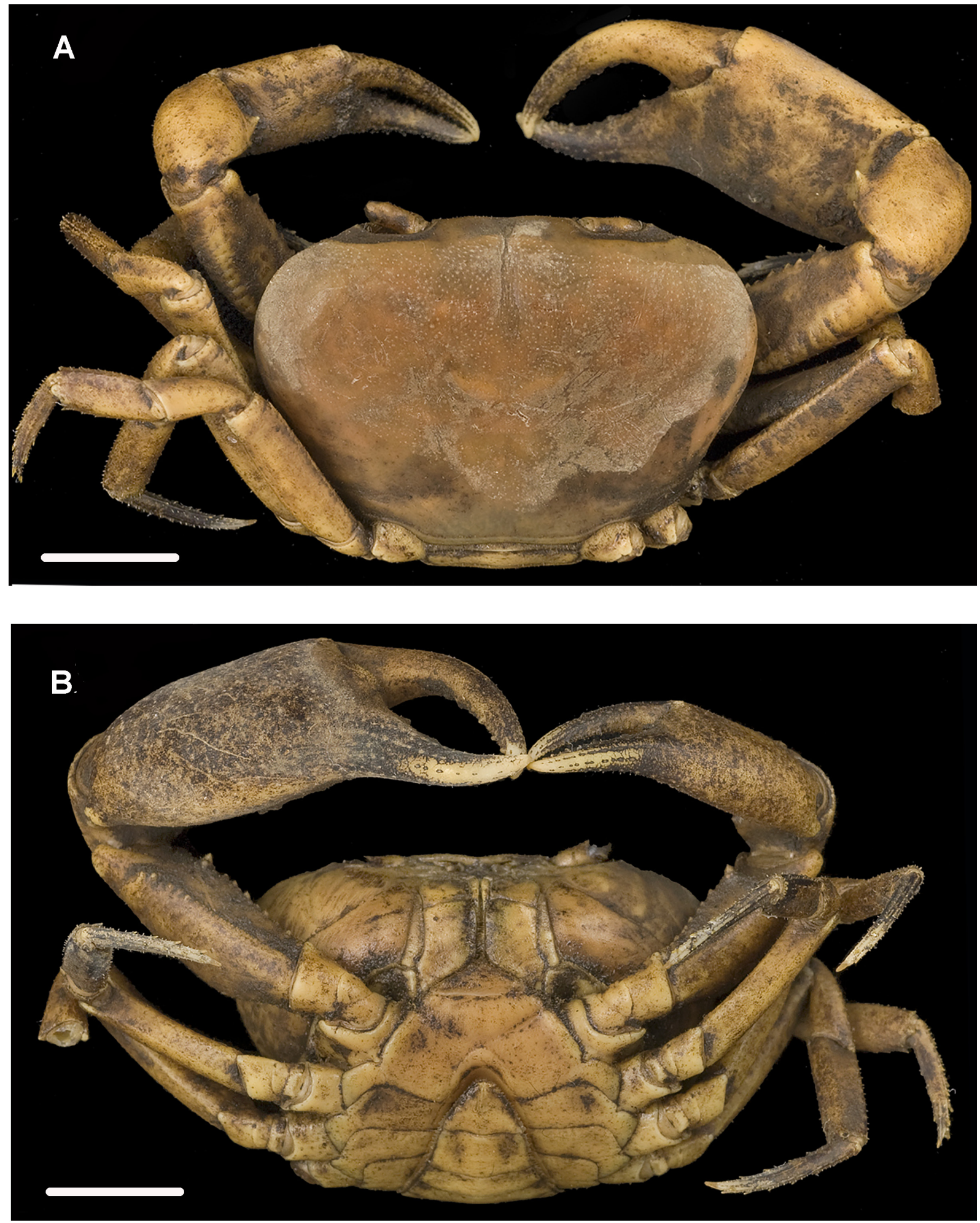

Fig. 1. Potamonautes entebbe sp. nov., holotype, adult $\widehat{\partial}, \mathrm{CW} 35 \mathrm{~mm}$, from Entebbe, southern Uganda (NHMUK 1955.11.8.26). A. Whole animal, dorsal view. B. Whole animal, ventral view. Scale bars: $6.3 \mathrm{~mm}$. Photographs by Phillip Crabb, NHMUK. 
Potamonautes entebbe sp. nov. differs from $P$. loveni and $P$. williamsi in that the proximal tooth on the inner margin of the cheliped carpus of $P$. entebbe sp. nov. is pointed and subequal to the distal tooth (Fig. 1A) (vs both teeth weak, low and blunt in $P$. loveni and $P$. williamsi). Potamonautes entebbe sp. nov. differs from $P$. aloysiisabaudiae, $P$. busungwe sp. nov., $P$. elgonensis and $P$. kantsyore sp. nov. in that the G1 terminal article of $P$. entebbe sp. nov. has a straight tip (Fig. 6A, D) (vs a G1 terminal article that has either a slightly or distinctly upcurved tip in these other species) (Chace 1942; Bott 1955; Cumberlidge \& Clark 2010a). Potamonautes entebbe sp. nov. differs from P. williamsi as follows: the distal tooth on the inner margin of the carpus of the cheliped is strong and pointed (Fig. 1A) (vs small and low in P. williamsi) and s3/s4 is deep at the edges and faint medially (Fig. 1B) (vs not visible except for two short notches on the external margins of the sternite in P. williamsi) (Cumberlidge \& Clark 2010a). Potamonautes entebbe sp. nov. differs from P. rukwanzi by the third maxilliped ischium, which has a faint, barely visible sulcus (Fig. 1B) (vs a distinct and complete sulcus in P. rukwanzi) (Corace et al. 2001).

Potamonautes busungwe sp. nov. urn:1sid:zoobank.org:act:C6828C1B-D256-4F44-8A89-270F9478CE38 Figs 2A-B, 4B, 5C-D, 6B, E, 7; Tables 1, 3

\section{Diagnosis}

Based on holotype (adult male CW $15.9 \mathrm{~mm})$. Carapace outline transversely oval, medium height $(\mathrm{CH} /$ FW 1.0); exorbital tooth low, blunt, epibranchial tooth reduced to granule, postfrontal crest complete but faint, lateral ends meeting epibranchial teeth; anterolateral margin posterior to epibranchial tooth smooth (Fig. 2A); carapace sidewall vertical sulcus meeting anterolateral margin. Third maxilliped ischium smooth, lacking vertical sulcus; s3/s4 deep at edges, faint in middle; margins of s4 distinctly raised, thickened (Fig. 2B). Chelipeds of adult male unequal; movable finger (dactylus) and fixed finger (propodus) of major cheliped of adult male both slim, elongated, both with series of small, even-sized teeth, dactylus highly arched, encompassing wide oval interspace when closed. Inferior margins of merus of cheliped lined by series of small pointed teeth, distal tooth large, pointed; superior surface of merus granulated (Fig. 2B). Distal, proximal teeth on inner margin of cheliped carpus small, low, equalsized (Fig. 2B). G1 terminal article short $(0.25 \times$ length of G1), straight, in line with longitudinal axis of subterminal segment, distal third curving outward, tapering to slightly upcurved tip (Fig. 6B, E).

\section{Etymology}

The new species is named for the small island of Busungwe in the northwestern part of Lake Victoria near the border with Tanzania, where this species was first collected, and is used as a noun in apposition (Fig. 7). Vernacular name: the Busungwe crab.

\section{Material examined}

Holotype (here designated)

UGANDA: adult $\widehat{\partial}$, CW 15.9, CL 10.6, CH 5.4, FW 5.3 mm, Central Region, Kakuuto, Busungwe Island, $-0.953781^{\circ} \mathrm{S}, 31.783557^{\circ} \mathrm{E}$, exposed rocky shore, 21 Apr. 1955, P. Corbett leg., East African Fisheries Research Organization (NHMUK 2017.37).

Paratype (here designated)

UGANDA: adult ovigerous +, CW 15.4, CL 10.5, CH 5.3, FW 5.3 mm, Central Region, Kakuuto, Busungwe Island, $-0.950000^{\circ} \mathrm{S}, 31.7833^{\circ} \mathrm{E}$, exposed rocky shore, same date and collector as for holotype (NHMUK 2015.3056).

\section{Description}

Carapace of medium height ( $\mathrm{CH} / \mathrm{FW} 1.0$; Fig. 2A), front broad, measuring one-third $\mathrm{CW}(\mathrm{FW} / \mathrm{CW}$ 0.33; Fig. 2B). Semi-circular, urogastric, cardiac, posterior and cervical carapace grooves all distinct. 
Postfrontal crest complete, faint, lateral ends meeting epibranchial teeth; epigastric crests faint, median sulcus between crests short, forked posteriorly; exorbital tooth low, blunt; epibranchial tooth reduced to granule; anterolateral margin between exorbital, epibranchial teeth smooth, curving slightly outward, lacking intermediate tooth; anterolateral margin posterior to epibranchial tooth smooth (Fig. 2A);
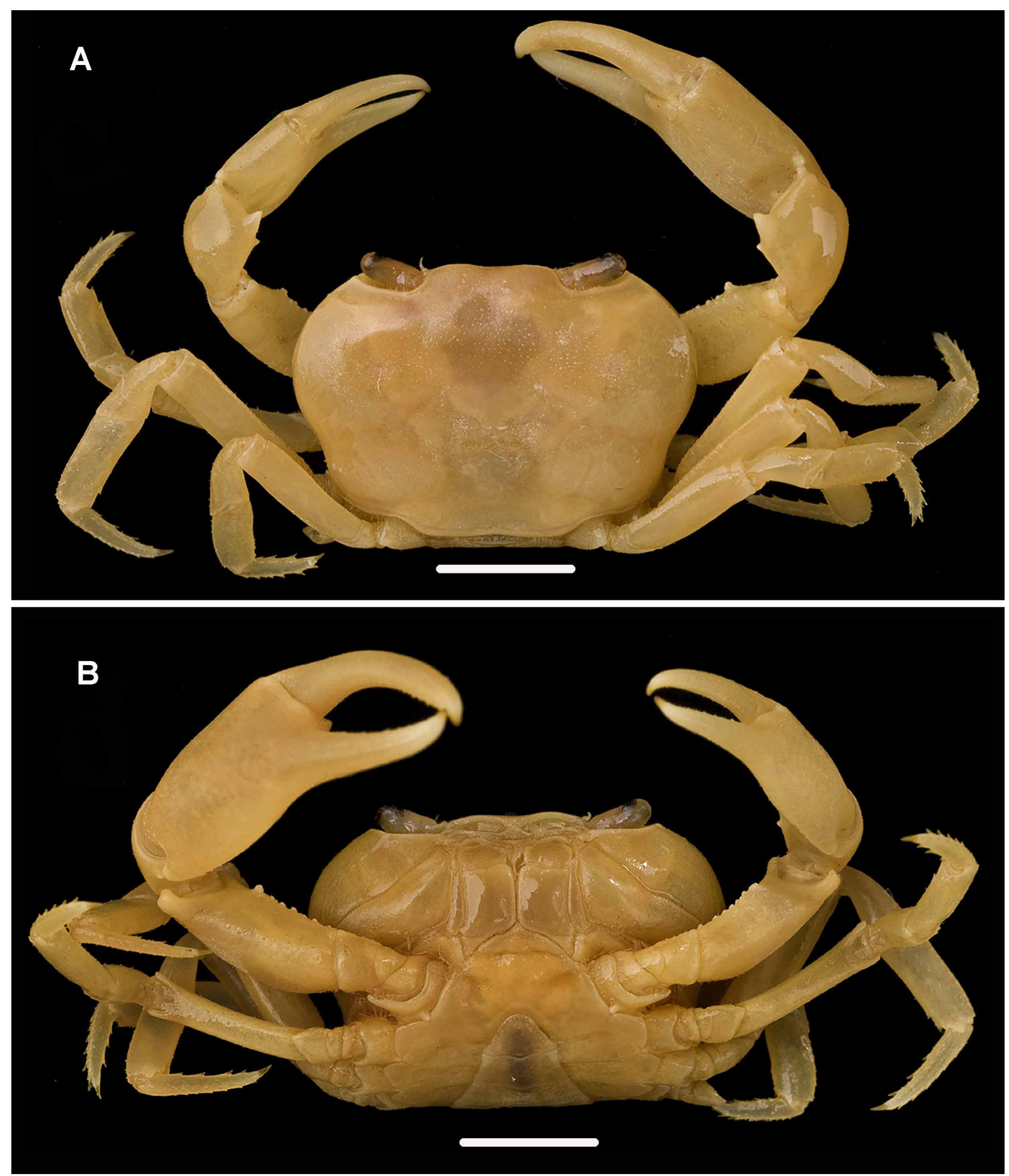

Fig. 2. Potamonautes busungwe sp. nov, holotype, adult $\widehat{\partial}, \mathrm{CW} 15.9 \mathrm{~mm}$, from Busungwe Island, Lake Victoria, southern Uganda (NHMUK 2017.37). A. Whole animal, dorsal view. B. Whole animal, ventral view. Scale bars: $6.3 \mathrm{~mm}$. Photographs by Phillip Crabb, NHMUK. 
carapace sidewall vertical sulcus faint, meeting longitudinal sulcus, dividing sidewall into three parts (Figs 2B, 4B). Suborbital margin granulated (Figs 2B, 4B). Third maxilliped exopod with long flagellum, ischium smooth, lacking vertical sulcus (Figs 2B, 4B). Epistomial tooth large, triangular, edges lined by large round granules. Mandibular palp 2-segmented; terminal segment simple; s2/s3 deep, completely crossing sternum; s3/s4 deep at edges, faint in middle; s4/e4, s5/e5, s6/e6 and s7/e7 all visible (Fig. 2B). Chelipeds of adult male unequal; movable finger (dactylus) and fixed finger (propodus) of major cheliped of adult male slim, elongated, with series of small, even-sized teeth, dactylus highly arched, encompassing wide oval interspace when closed (Fig. 5C-D). Inferior margins of merus of cheliped lined by series of small pointed teeth, distal tooth large, pointed; superior surface of merus granulated (Fig. 2B). Cheliped carpus inner margin teeth both small, low, equal-sized. Pleon outline broadly triangular, with straight edges (Fig. 2B). G1 terminal article short $(0.25 \times$ length of G1), straight, in line with longitudinal axis of subterminal segment, distal third curving outward, tapering to slightly upcurved tip (Fig. 6B, E). G2 terminal article long $(0.5 \times$ length of G2), flagellum-like.

Size. Small species, adult at CW $15 \mathrm{~mm}$.

CoLour. Preserved specimens uniformly light brown.

\section{Distribution}

Busungwe Island in the northern part of Lake Victoria (Fig. 7). The nearest town on the mainland to Busungwe is Kakuuto, in the Rakai District of the Central Region of southwestern Uganda.

\section{Ecology}

Little is known about the ecology of this species. These specimens were collected in 1955 by P. Corbett of the East African Fisheries Research Organization based at Jinja, who sampled offshore islands including Busungwe as part of a study of the fisheries of Lake Victoria. This small island is still relatively undisturbed, with only a few buildings on the northern part of the island.

\section{Conservation status}

An IUCN extinction risk assessment of $P$. busungwe sp. nov. has not yet been carried out, but given the fact that this species is known for only two specimens from a single locality, it would probably be regarded as Data Deficient.

\section{Remarks}

Potamonautes busungwe sp. nov. is superficially similar to several other species in this genus from Uganda that share the following characters: reduced exorbital and epibranchial teeth; a smooth anterolateral margin immediately behind the epibranchial tooth; an incomplete s3/s4 which is deep at the sides but absent in the middle; a male major cheliped with a slim, highly arched dactylus. Ugandan crabs that share this suite of characters include P. rukwanzi, P. williamsi, P. mutandensis (Chace, 1942), P. morotoensis and P. imatongensis.

Potamonautes busungwe sp. nov. can be distinguished from P. rukwanzi by its postfrontal crest, which is faint but complete (Fig. 2A) (vs distinct and complete in P. rukwanzi), by its third maxilliped ischium, which lacks a sulcus (Fig. 2B) (vs a deep sulcus in P. rukwanzi) by a sharp and pointed distal tooth on the cheliped merus (Fig. 2A-B) (vs a small, blunt and low distal tooth in P. rukwanzi), and by the G1 terminal article that ends in a slightly upturned tip (Fig. 6B, E) (vs an article that turns sharply upward at the tip in P. rukwanzi). Potamonautes busungwe sp. nov. differs from P. williamsi, P. mutandensis, $P$. morotoensis and P. imatongensis in that the distal tooth on the inner margin of the cheliped carpus of $P$. busungwe sp. nov. is strong and pointed (vs a weak, low and blunt distal carpal tooth in these four 
Table 3. Size range of the seven smallest known species of Afrotropical freshwater crabs. The range of the pubertal moult was estimated to be the size range between the carapace width $(\mathrm{CW})$ of the largest subadult female and the CW of the smallest adult female. Based on Cumberlidge et al. (1999: table 2) and Marijnissen et al. (2004: table 2). See text for a discussion of how to establish the size range of a species of freshwater crab and for the taxonomic authorities of the species in this table.

\begin{tabular}{|c|c|c|c|c|}
\hline Species & $\begin{array}{c}\text { Pubertal } \\
\text { moult } \\
(\mathrm{CW} \text { mm })\end{array}$ & $\begin{array}{l}\text { Largest known } \\
\text { specimen } \\
\text { (CW mm) }\end{array}$ & Distribution & Habitat \\
\hline Platythephusa maculata & 11.0 & 17.9 & $\begin{array}{c}\text { Lake Tanganyika } \\
\text { (Zambia) }\end{array}$ & $\begin{array}{l}\text { Inside empty mollusc } \\
\text { shells, } 1-60 \mathrm{~m} \text { deep }\end{array}$ \\
\hline Platythephusa conculcata & 11.3 & 30.3 & $\begin{array}{c}\text { Lake Tanganyika } \\
\text { (DR Congo, Burundi, } \\
\text { Zambia) }\end{array}$ & $\begin{array}{l}\text { Under rocks, } \\
2-5 \mathrm{~m} \text { deep }\end{array}$ \\
\hline Platythephusa polita & 11.4 & 18.0 & $\begin{array}{c}\text { Lake Tanganyika } \\
\text { (DR Congo, Burundi, } \\
\text { Tanzania) }\end{array}$ & $\begin{array}{l}\text { Inside empty mollusc } \\
\text { shells, 5-60 m deep }\end{array}$ \\
\hline Platythephusa echinata & 12.6 & 39.0 & $\begin{array}{l}\text { Lake Tanganyika } \\
\text { (Burundi, Tanzania) }\end{array}$ & $\begin{array}{l}\text { Inside empty mollusc } \\
\text { shells, } 10-30 \mathrm{~m} \text { deep }\end{array}$ \\
\hline Potamonautes busungwe sp. nov. & 15.4 & 15.9 & Lake Victoria, Uganda & $\begin{array}{l}\text { Rocky shores of } \\
\text { Busungwe Island }\end{array}$ \\
\hline Potamonautes kantsyore sp. nov. & 15.6 & 16.1 & Kagera River, Uganda & $\begin{array}{c}\text { Kantsyore, an island } \\
\text { in the river }\end{array}$ \\
\hline Platythephusa immaculata & 16.9 & 31.0 & $\begin{array}{c}\text { Lake Tanganyika } \\
\text { (Zambia) }\end{array}$ & 40-80 m deep \\
\hline
\end{tabular}

species). Potamonautes busungwe sp. nov. differs from P. morotoensis and P. imatongensis by the G1 terminal article whose tip is slightly upcurved in P. busungwe sp. nov. (Fig. 6B, E) (vs a G1 terminal article with a tip that turns sharply upward in P. morotoensis and P. imatongensis). Potamonautes busungwe sp. nov. can be distinguished from $P$. entebbe sp. nov. by an examination of $\mathrm{s} 3 / \mathrm{s} 4$, which is reduced to two short notches at the edges and faint in the middle (Fig. 2B) (vs V-shaped and deepest at the edges and faintest in the middle in P. entebbe sp. nov.; Fig. 1B).

Potamonautes kantsyore sp. nov. urn:1sid:zoobank.org:act:8EB2261D-E474-4809-B415-382269BF354E

Figs 3A-B, 4C, 5E-F, 6C, F, 7; Tables 1, 3

\section{Diagnosis}

Carapace of medium height (CH/FW 1.2; Fig. 3B); exorbital tooth low, blunt, epibranchial tooth reduced to granule, postfrontal crest complete, faint medially, lateral ends well defined, meeting epibranchial teeth; anterolateral margin posterior to epibranchial tooth finely serrate, almost smooth (Fig. 3A); carapace sidewall vertical sulcus meeting anterolateral margin (Fig. 3B). Third maxilliped ischium with vertical sulcus (Fig. 3B); s3/s4 not visible except for two short deep notches at edges (Fig. 3B). Inferior margins of merus of cheliped with series of small granules, distal tooth pointed; cheliped carpus distal tooth large, pointed, proximal tooth small, one-third as large as distal tooth (Fig. 3B). Fixed finger (propodus) of major cheliped of adult male with large teeth along cutting edges, largest molars proximal, movable finger (dactylus) cutting edge with only small even granules, dactylus not arched, encompassing long narrow interspace when closed (Fig. 5F). G1 terminal article straight, directed outward at $45^{\circ}$ angle to longitudinal axis of subterminal segment, curving outward throughout, tip slightly upturned (Fig. 6C, F). 


\section{Etymology}

The new species is named for Kantsyore Island, which is located in the Kagera River (where it is about $130 \mathrm{~m}$ wide) at a locality that is about $120 \mathrm{~km}$ west of the point where the river enters Lake Victoria. The name is used as a noun in apposition. Vernacular name: the Kantsyore Island crab.

\section{Material examined}

Holotype (here designated)

UGANDA: adult 3 , CW 16.8, CL 11.6, CH 5.5, FW 4.6 mm, Ankole, Mbarara District, Kantsyore (Toni Nuti's) Island, in the Kagara River, $12.9 \mathrm{~km}$ E of Kikagati, $-1.04216^{\circ} \mathrm{S}, 30.67056^{\circ} \mathrm{E}, 1280 \mathrm{~m}$ a.s.l., 19-20 Aug. 1967, J.S. Williams leg. (NHMUK 2017.29).

\section{Paratypes}

UGANDA: 1 adult ${ }^{\lambda}$, CW 15.6, CL 11.6, CH 5.5, FW $4.6 \mathrm{~mm}$, same collection data as for holotype

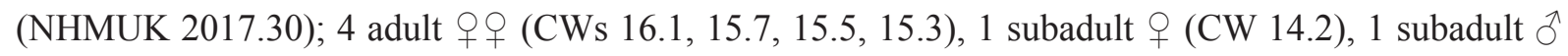
(CW $13.2 \mathrm{~mm}$ ), same collection data as for holotype (NHMUK 2017.31-36).

\section{Description}

Carapace of medium height (CH/FW 1.2; Fig. 3B); front broad, measuring one-third CW (FW/CW 0.3; Fig. 3A). Semi-circular, urogastric, cardiac, posterior and cervical carapace grooves all faint. Postfrontal crest complete, faint, lateral ends well defined, meeting epibranchial teeth; exorbital tooth low, blunt. Epigastric crests faint, median sulcus between crests short, forked posteriorly. Epibranchial tooth reduced to granule; anterolateral margin between exorbital, epibranchial teeth smooth, curving slightly outward, lacking intermediate tooth; anterolateral margin posterior to epibranchial tooth finely serrate, almost smooth (Fig. 3A); carapace sidewall vertical sulcus faint, incomplete, beginning at longitudinal sulcus, not meeting anterolateral margin, dividing sidewall into three parts (Fig. 4C). Suborbital margin granulated (Fig. 4C). Third maxilliped exopod with long flagellum, ischium with faint vertical sulcus (Fig. 4C). Epistomial tooth large, triangular, edges lined by large, round granules (Fig. 4C). Mandibular palp 2-segmented; terminal segment simple, s2/s3 deep, completely crossing sternum; s3/s4 not visible except for 2 short, deep notches at edges; margins of s4 flat, not raised; s4/e4, s5/e5, s6/e6 and s7/e 7 all faint. Inferior margins of merus of cheliped with series of small granules, distal tooth pointed; two teeth on inner margin of cheliped carpus, both small, pointed; superior surface of merus granulated (Fig. 3B). Fixed finger (propodus) of major cheliped of adult male with large teeth along cutting edges, largest molars proximal, movable finger (dactylus) cutting edge with only small, even granules, dactylus not arched, encompassing long narrow interspace when closed (Fig. 5E-F). Pleon outline broadly triangular, with straight edges (Fig. 3B). G1 terminal article straight, directed outward at $45^{\circ}$ angle to longitudinal axis of subterminal segment, with slightly upturned tip (Fig. 6C, F), G2 terminal article long $(0.5 \times$ length of G2), flagellum-like.

Size. Small species, adult size range between CW 15.3 and $16.8 \mathrm{~mm}$.

CoLour. Preserved specimens uniformly light brown.

\section{Distribution}

This species is known from only a single locality on Kantsyore Island in the Kagara River, $12.9 \mathrm{~km}$ east of Kikagati, where the river forms the border between Uganda and Tanzania (Fig. 7). 

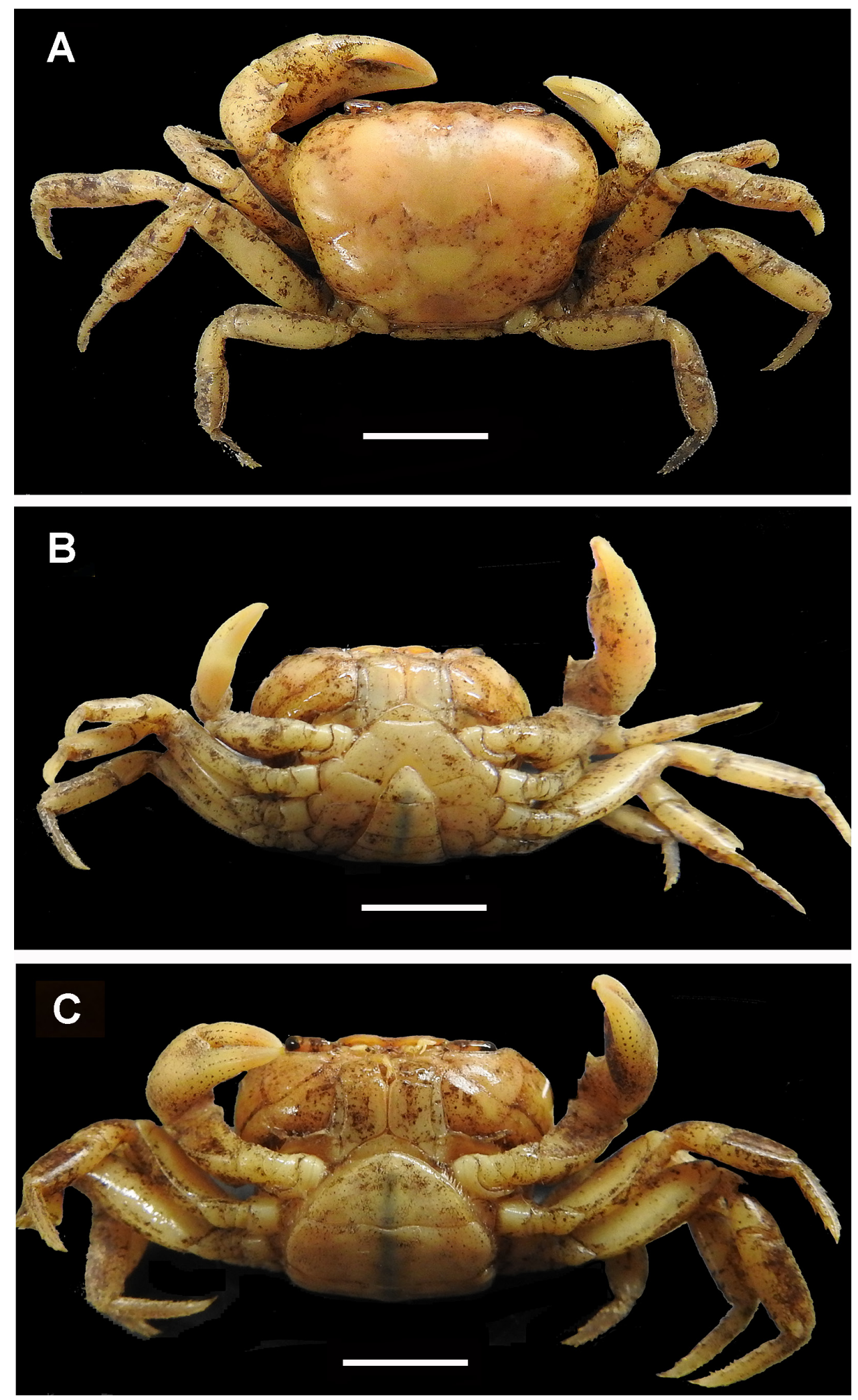

Fig. 3. Potamonautes kantsyore sp. nov. from Kantsyore Island in the Kagera River, southern Uganda. A-B. Holotype, adult $\partial$, CW $16.8 \mathrm{~mm}$, (NHMUK 2017.29). A. Whole animal, dorsal view. B. Whole animal, ventral view. C. Paratype, adult 9 , CW $16.1 \mathrm{~mm}$, (NHMUK 2017.33), whole animal, ventral view. Scale bars: $\mathrm{A}-\mathrm{B}=6.1 \mathrm{~mm} ; \mathrm{C}=6.4 \mathrm{~mm}$. 


\section{Ecology}

This river-living species was captured on Kantsyore Island in the Kagera River (water temperature $20-24^{\circ} \mathrm{C}$ ) from between tree roots using meat as bait. The new species was collected in the same stretch of river as $P$. niloticus, a large-bodied, widely distributed species found throughout the Nile River basin (Cumberlidge 2009; Cumberlidge \& Clark 2010b).

\section{Conservation status}

An IUCN extinction risk assessment of Potamonautes kantsyore sp. nov. has not yet been carried out, but given the fact that this species is known for only a few specimens from a single locality, it would probably be regarded as Data Deficient.

\section{Remarks}

Potamonautes kantsyore sp. nov. is superficially similar to several other species in this genus that share the following characters: reduced or absent exorbital and epibranchial teeth; a smooth anterolateral margin immediately behind the epibranchial tooth; and a thoracic sternum with a $\mathrm{s} 3 / \mathrm{s} 4$ which is incomplete and deep at the sides but faint or absent in the middle. Ugandan crabs that share this suite of characters include P. rukwanzi, P. williamsi, P. mutandensis, P. morotoensis and P. imatongensis. Potamonautes emini (Hilgendorf, 1892), from a geographically close locality in northwestern Tanzania, was also compared.

Potamonautes kantsyore sp. nov. can be distinguished from P. rukwanzi by the distal tooth on the cheliped merus, which is large, sharp and pointed in P. kantsyore sp. nov. (Fig. 3B) (vs small, blunt and low in P. rukwanzi). Potamonautes kantsyore sp. nov. differs from P. willliamsi, P. mutandensis, P. morotoensis and P. imatongensis in that the proximal tooth on the inner margin of the cheliped carpus of P. kantsyore sp. nov. is pointed and almost as large as the distal tooth (Fig. 3A) (vs a weak, low and blunt proximal tooth in the other species) and the ischium of the third maxilliped is smooth in P. kantsyore sp. nov. (Fig. 3B) (vs with a distinct vertical sulcus in the other species). Potamonautes kantsyore sp. nov. is superficially similar to P. emini from northwest Tanzania (Reed \& Cumberlidge 2006) in that both are small species and both have smooth carapace margins. The most important differences between these two species are that the postfrontal crest is weak in P. kantsyore sp. nov. (vs distinct in P. emini) and the ischium of the third maxilliped has a faint vertical sulcus in P. kantsyore sp. nov. (vs smooth in P. emini) (Bott 1955: pl. XIV, figs 1a-d; Reed \& Cumberlidge 2006; Meyer \& Cumberlidge 2011). Potamonautes kantsyore sp. nov. can be distinguished from $P$. entebbe sp. nov. by examination of $\mathrm{s} 3 / \mathrm{s} 4$, which is almost completely absent except for two short notches on the external margins of the sternite (Fig. 3B) (vs deep at the edges and faint in the middle in P. entebbe sp. nov., Fig. 1B). Finally, P. kantsyore sp. nov. can be distinguished from $P$. busungwe sp. nov. by examination of the ischium of the third maxilliped, which has a faint vertical sulcus (Fig. 3B) (vs smooth in P. busungwe sp. nov.; Fig. 2B).

\section{Discussion}

\section{History of the freshwater crabs of Uganda}

Between 1837 and 1942, five species of freshwater crabs were described from Uganda (Table 1). The major taxonomic revision of Bott (1955) radically altered our understanding of Uganda's freshwater crab fauna (Table 2). Although Bott (1955) recognized six species from Uganda, only three of these (P. niloticus, P. aloysiisabaudiae and P. granviki (Colosi, 1924)) were included in that work (Table 2). The other two Ugandan species (P. mutandensis and P. amalerensis) were considered by Bott (1955) to be subspecies of other taxa (P. emini and P. didieri (Rathbun, 1904), respectively). One consequence of these synonymies was that the distributional ranges of the parent species were expanded to include Uganda (Table 2). Bott (1955) listed a third species, P. berardi (Audouin, 1826), as occurring in Uganda, but this was based on misidentified specimens from Mount Elgon (Table 2). 

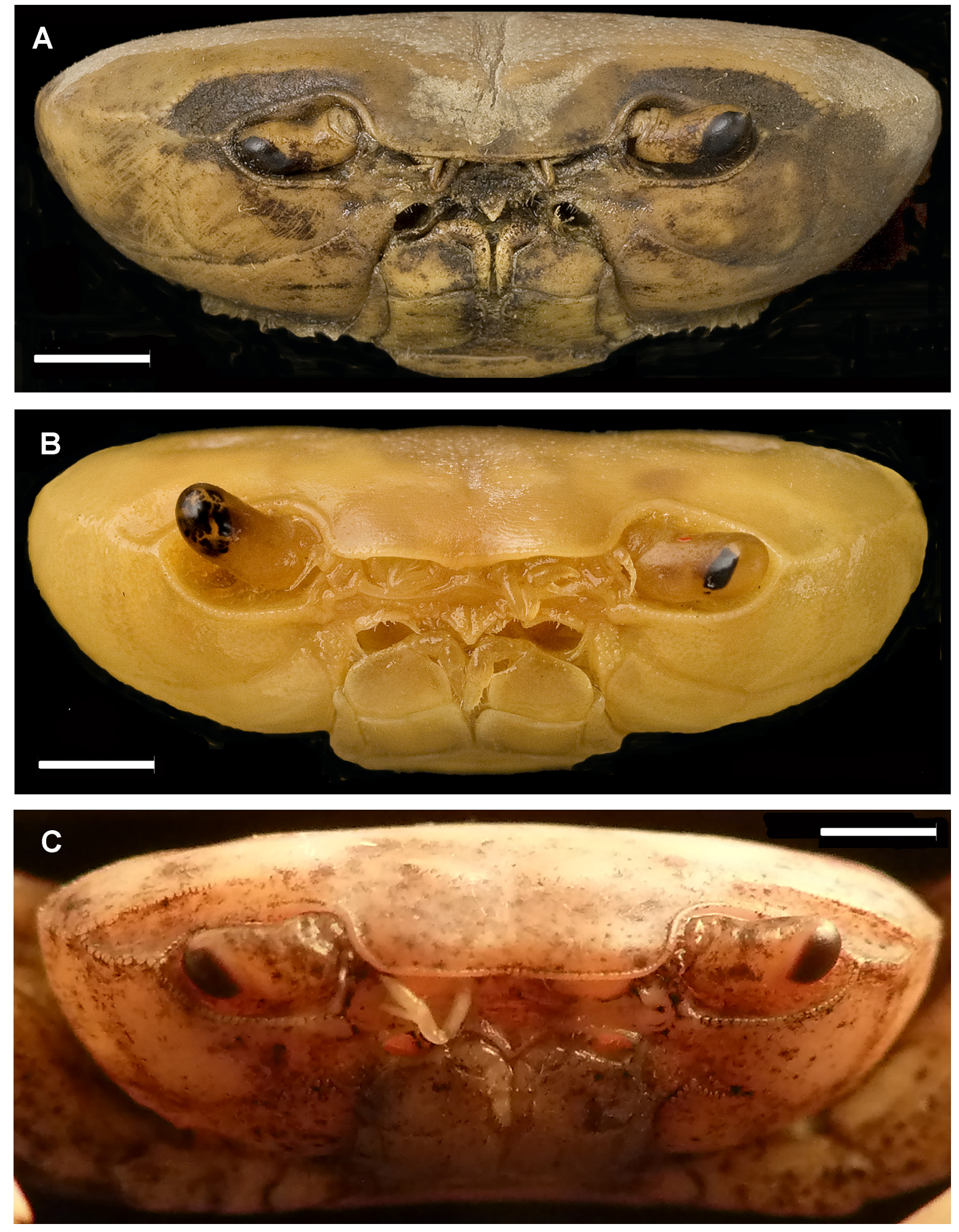

Fig. 4. Frontal view of carapace. A. Potamonautes entebbe sp. nov., holotype, adult $\widehat{\partial}$, CW $35 \mathrm{~mm}$, from Entebbe, Lake Victoria, southern Uganda (NHMUK 1955.11.8.26). - B. P. busungwe sp. nov., holotype, adult $\hat{\jmath}$, CW $21.5 \mathrm{~mm}$, from Busungwe Island, Lake Victoria,, southern Uganda (NHMUK 2017.37). C. P. kantsyore sp. nov., holotype, adult $\widehat{\jmath}$, CW $16.8 \mathrm{~mm}$, from Kantsyore Island in the Kagera River, southern Uganda (NHMUK 2017.29). Scale bars: A $=2.34 \mathrm{~mm}$; $=3.1 \mathrm{~mm} ; \mathrm{C}=3.3 \mathrm{~mm}$. Photographs A-B by Phillip Crabb, NHMUK. 
The modern understanding of African freshwater crab taxonomy, which developed after the monograph of Bott (1955), has radically altered the classification of this group and has revised the species lists for each country including Uganda (Table 1). For example, taxonomic revisionary work based on new material, and in some cases phylogenetic data, has affected the status of taxa from Uganda with the result that the scheme of Bott (1955) (Table 2) is no longer accepted. Three species (P. berardi, P. emini and $P$. didieri) are removed here from the species list for Uganda established by Bott (1955), and P. granviki from Mount Elgon is now treated as a junior synonym of $P$. loveni from Mount Elgon and western Kenya (Williams 1991; Cumberlidge \& Clark 2010b, table 1). In addition, P. mutandensis and $P$. amalerensis are both recognized as valid species endemic to Uganda (Cumberlidge \& Meyer 2011; Cumberlidge \& Clark 2016), and the range of Sudanonautes floweri (De Man, 1901) has been expanded to include northwest Uganda (Cumberlidge 2009). Furthermore, eight new species of Ugandan freshwater crabs have been described since 2001 (Corace et al. 2001; Cumberlidge \& Clark 2010a, 2010b, 2016, present work: Table 1).
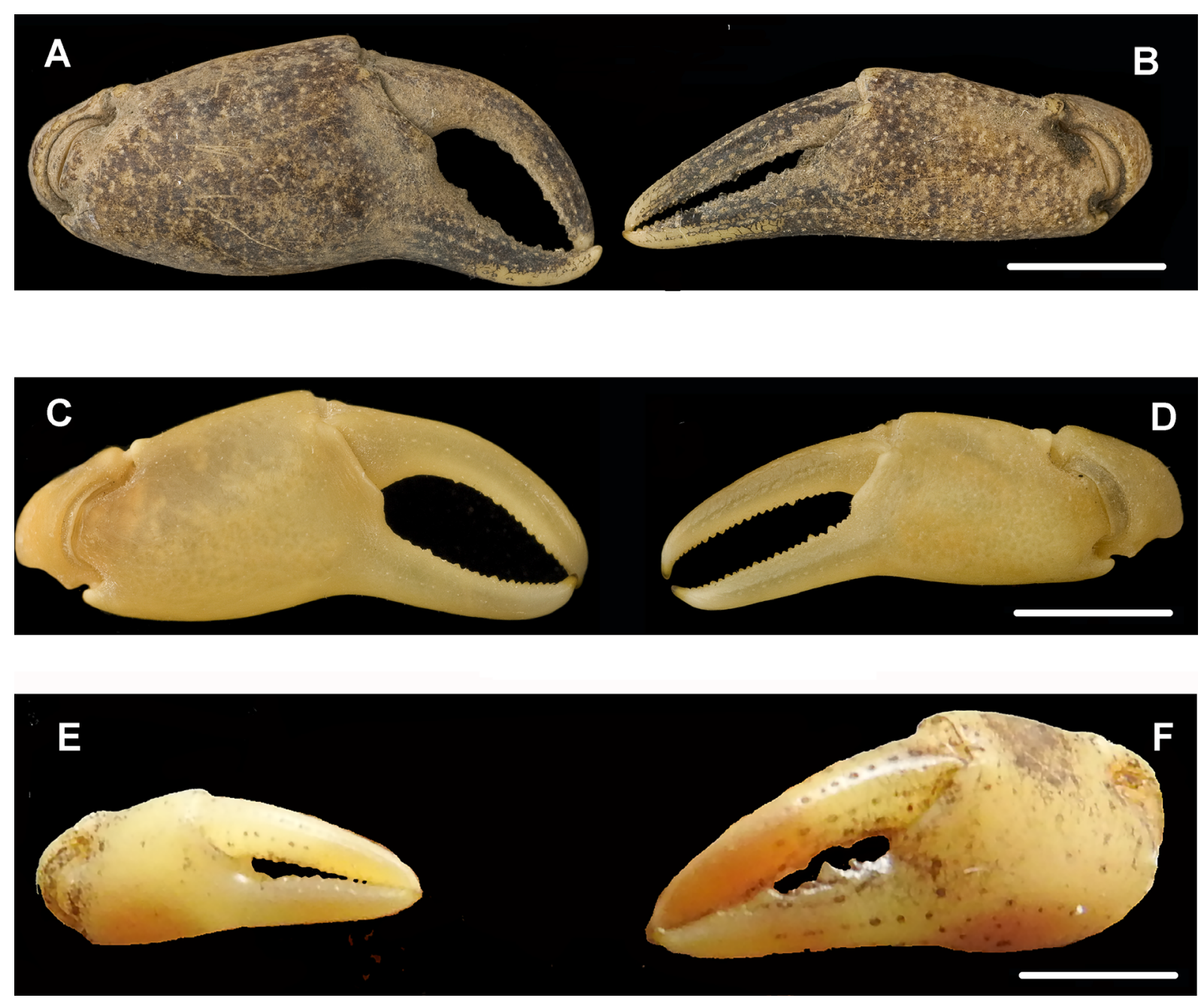

Fig. 5. Frontal view of left and right chelipeds. A-B. Potamonautes entebbe sp. nov., holotype, adult o, CW $35 \mathrm{~mm}$, from Entebbe in southern Uganda (NHMUK 1955.11.8.26). - C-D. Potamonautes busungwe sp. nov., holotype, adult $\hat{\partial}$, CW $21.5 \mathrm{~mm}$, from Entebbe in southern Uganda (NHMUK

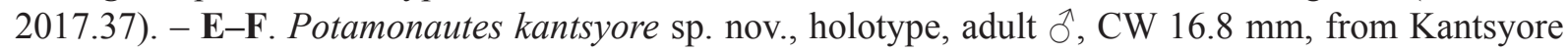
Island in the Kagera River in southern Uganda (NHMUK 2017.29). Scale bar: A-B $=2.3 \mathrm{~mm}$; $\mathrm{C}-\mathrm{D}=$ $3.1 \mathrm{~mm}$; E-F = $3.3 \mathrm{~mm}$. Photographs A-D by Phillip Crabb, NHMUK. 

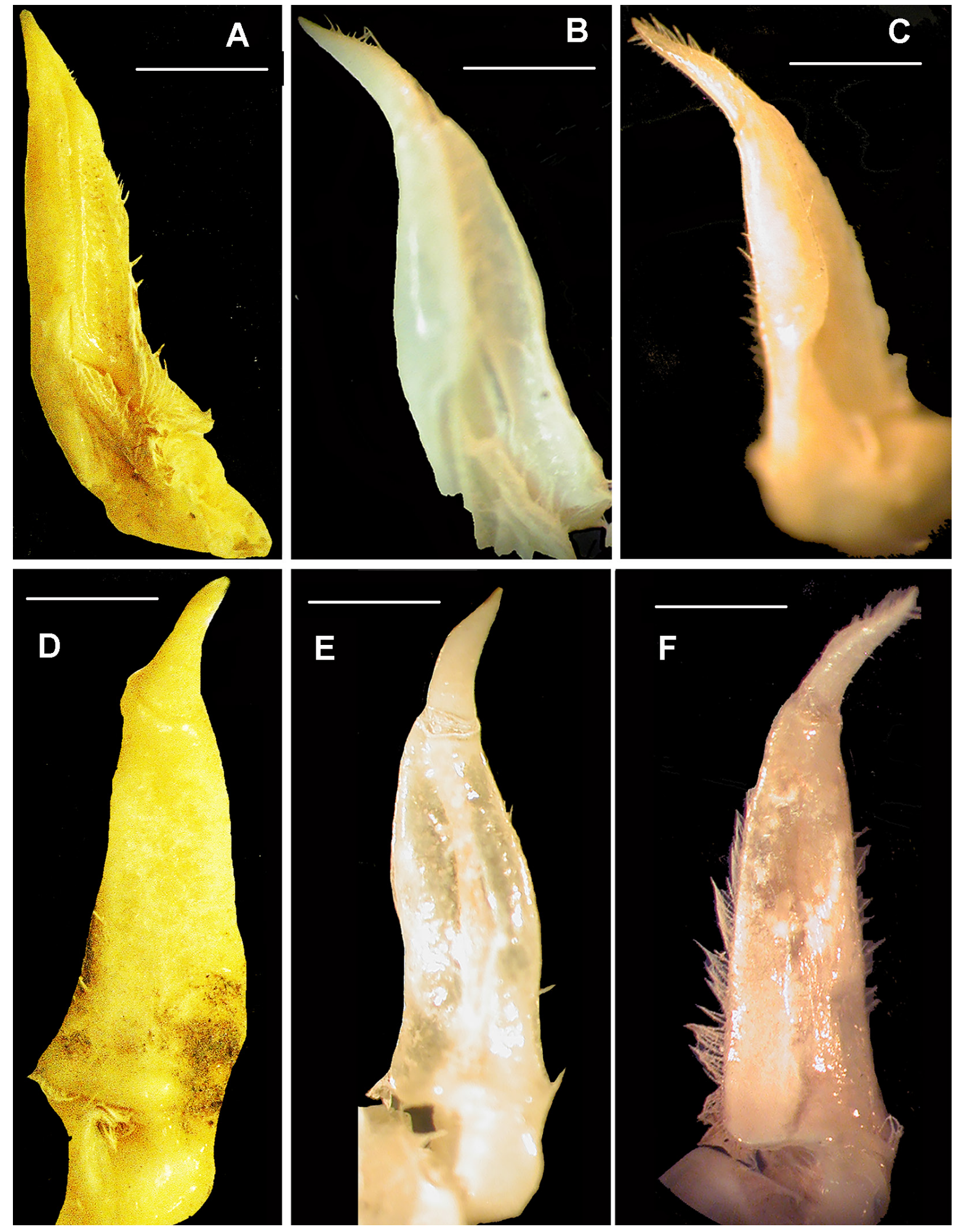

Fig. 6. G1, ventral view (A-C) and dorsal view (D-F). A, D. Potamonautes entebbe sp. nov., holotype, adult Ô, CW $35 \mathrm{~mm}$, from Entebbe, southern Uganda (NHMUK 1955.11.8.26). - B, E. P. busungwe sp. nov., holotype, adult $\widehat{\jmath}, \mathrm{CW} 21.5 \mathrm{~mm}$, from Busungwe Island, Lake Victoria (NHMUK 2017.37). - C, F. P. kantsyore sp. nov., holotype, adult $\sigma^{\lambda}$, CW $16.8 \mathrm{~mm}$, from Kantsyore Island in the Kagera River, southern Uganda (NHMUK 2017.29). Scale bars: A, D =2.3 mm; B, E = $3.1 \mathrm{~mm}$; C, F = $3.3 \mathrm{~mm}$ 


\section{Concluding remarks}

Two of the new species described here (P. busungwe sp. nov. and $P$. kantsyore sp. nov.) are the smallest species of freshwater crabs assigned to Potamonautes known from Africa. Four miniature species of shelldwelling crabs of the endemic genus Platythelphusa A. Milne-Edwards, 1887, from Lake Tanganyika are the smallest known species of African freshwater crabs (Cumberlidge et al. 1999; Marijnissen et al. 2004), and are even smaller than the Ugandan species (Table 3). The small Lake Tanganyika species are Platythelphusa polita Capart, 1952, P. conculcata (Cunnington, 1907), P. maculata (Cunnington, 1899) and P. echinata Capart, 1952 (with adult size ranges beginning at CWs 11.0, 11.3, 11.4 and $12.6 \mathrm{~mm}$ respectively; Capart 1952; Cumberlidge et al. 1999; Table 3).

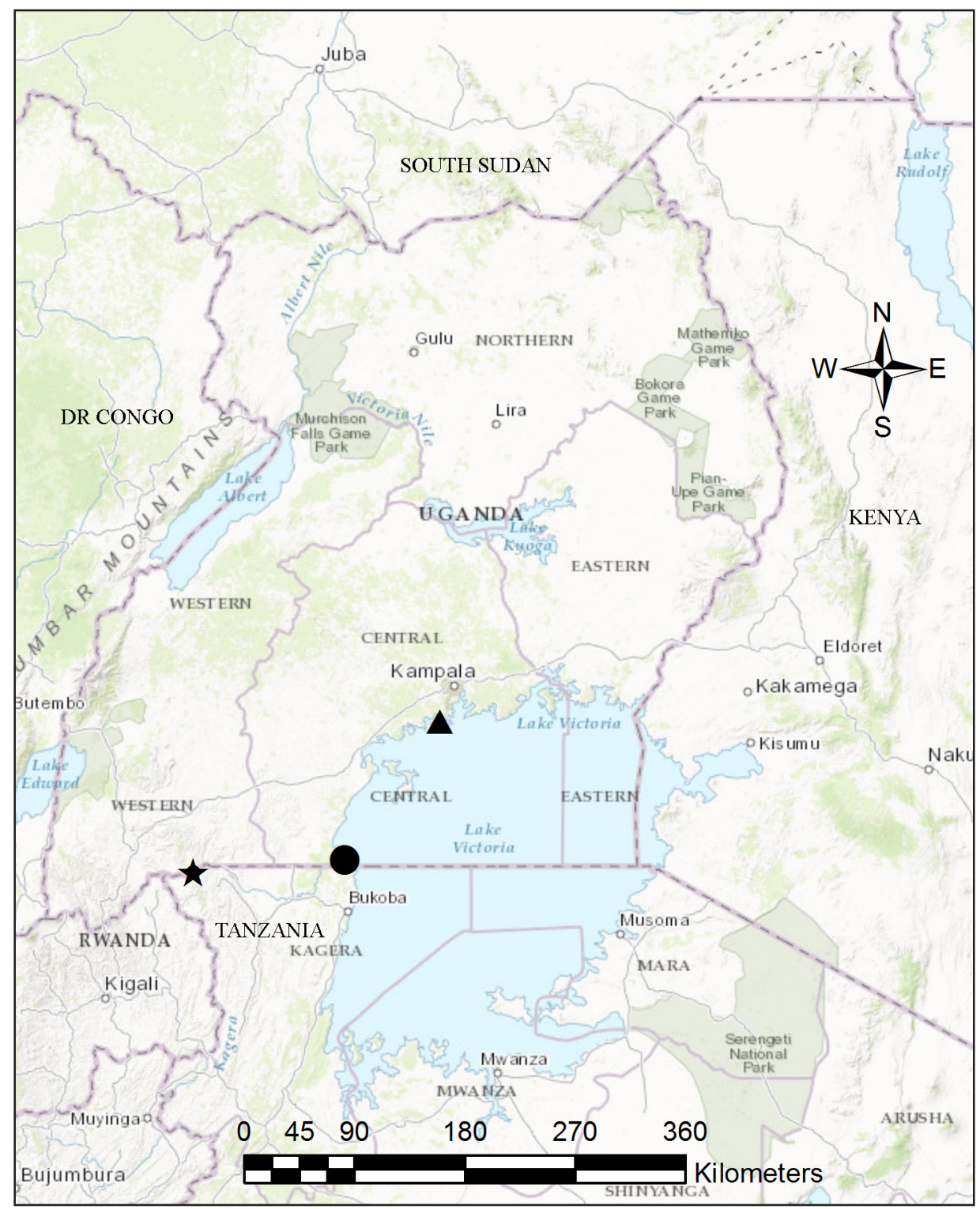

Fig. 7. Distribution map showing the known localities of Potamonautes entebbe sp. nov. (black triangle), P. busungwe sp. nov. (black circle) and P. kantsyore sp. nov. (black star) in Uganda, East Africa. For exact localities, see text. 
Until the present study, it was thought that P. niloticus was the only species of freshwater crab found in Lake Victoria. Potamonautes niloticus is a large commercially exploited species that is widespread throughout the Nile River drainage basin (from Egypt to Rwanda) and is not endemic to Lake Victoria (Cumberlidge 2009; Cumberlidge \& Clark 2010a). The present study raises the possibility that there are three species of freshwater crabs living in Lake Victoria $-P$. niloticus, $P$. entebbe sp. nov. and P. busungwe sp. nov. - rather than one non-endemic species (P. niloticus), and that the two new species described here are the first endemic species known from this lake.

The other small species discovered in the present study is P. kantsyore sp. nov. (adult at CW $15.3 \mathrm{~mm}$ ), which is endemic to Kantsyore Island in a widened stretch of the Kagera River, about $120 \mathrm{~km}$ west of the point where the river enters Lake Victoria. The Kagera River arises in Burundi and is thought to be one of the sources of the Nile River. In Burundi the Kagera River flows north along the Rwanda-Burundi and Rwanda-Tanzania borders, and then turns east where it follows the Tanzania-Uganda border before eventually emptying into Lake Victoria in Uganda.

\section{Acknowledgements}

We would like to acknowledge support from Northern Michigan University (NMU) Faculty Grant Award \#554901 and the useful contributions of NMU biology students Harrison Moynihan and Wesley S. Bos, who assisted the authors in part of this work.

\section{References}

Barnley G.R. \& Prentice M.A. 1958. Simulium neavei in Uganda. East African Medical Journal 35: 475.

Bott R. 1955. Die Süßwasserkrabben von Afrika und ihre Stammesgeschichte. Annales du Musée royal du Congo belge 1 (3): 209-352.

Capart A. 1952. Crustacés, décapodes, brachyures. In: Exploration hydrobiologique du Lac Tanganyika (1946-1947), Resultats scientifiques Vol. III (3): 41-67. Institut royal des Sciences naturelles, Brussels.

Chace F.A. 1942. Scientific results of a fourth expedition to forested areas in eastern Africa, III: Decapod Crustacea. Bulletin of the Museum of Comparative Zoology at Harvard College 91: 185-233.

Corace R.G., Cumberlidge N. \& Garms R. 2001. A new species of freshwater crab from Rukwanzi, East Africa. Proceedings of the Biological Society of Washington 114: 178-187.

Crosskey R.W. 1990. The Natural History of Blackflies. John Wiley \& Sons, London.

https://doi.org/10.1002/rrr.3450080313

Cumberlidge N. 1999. The Freshwater Crabs of West Africa, Family Potamonautidae. Faune et Flore tropicales 35, IRD, Paris.

Cumberlidge N. 2009. Chapter 27. Freshwater crabs and shrimps (Crustacea: Decapoda) of the Nile Basin. In: Dumont H.J. (ed.) The Nile. Origin, Environments, Limnology and Human Use. Monographiae Biologicae 89: 547-561, Springer, New York.

Cumberlidge N. \& Clark P.F. 2010a. Two new species of freshwater crabs from Mt. Elgon, East Africa (Brachyura: Potamoidea: Potamonautidae) with a redescription of Potamonautes niloticus (H. Milne Edwards, 1837) and notes on their natural history. Journal of Natural History 44: 1807-1829.

https://doi.org/10.1080/00222931003678792

Cumberlidge N. \& Clark P.F. 2010b. A redescription of Potamonautes loveni (Colosi, 1924), a medically important freshwater crab from western Kenya and eastern Uganda, East Africa (Brachyura: Potamoidea: Potamonautidae). In: Castro P, Davie P.J.F., Ng P.K.L. \& Richer de Forges B. (eds) Studies on Brachyura: A Homage to Danièle Guinot. Crustaceana Monographs 11: 61-74. Brill, Leiden/Boston. 
Cumberlidge N. \& Clark P.F. 2016. Two new species of freshwater crabs from the highlands of northern Uganda, East Africa and a redescription of Potamonautes amalerensis (Rathbun, 1935) stat. rev. from Mount Kadam (Brachyura: Potamoidea: Potamonautidae). European Journal of Taxonomy 182: 1-18. https://doi.org/10.5852/ejt.2016.182

Cumberlidge N. \& Meyer K.S. 2011. The freshwater crabs of Lake Kivu, East Africa. Journal of Natural History 45 (29-30): 1835-1837. https://doi.org/10.1080/00222933.2011.562618

Cumberlidge N., Sternberg R. von, Bills I.R. \& Martin H.A. 1999. A revision of the genus Platythelphusa A. Milne-Edwards, 1887 from Lake Tanganyika, East Africa (Decapoda: Potamoidea: Platythelphusidae). Journal of Natural History 33 (10): 1487-1512. https://doi.org/10.1080/002229399299860

Marijnissen S.A.E., Schram F.R., Cumberlidge N. \& Michel E. 2004. Two new species of Platythelphusa A. Milne-Edwards, 1887 (Decapoda, Potamoidea, Platythelphusidae) and comments on the position of P. denticulata Capart, 1952 from Lake Tanganyika. Crustaceana 77: 513-532.

Meyer K.S. \& Cumberlidge N. 2011. A revision of the freshwater crabs (Crustacea: Decapoda: Brachyura: Potamonautidae) of the Lake Kivu drainage basin in Central and East Africa. Zootaxa 3011: 45-58.

Ng P.K.L., Guinot D. \& Davie P. 2008. Systema Brachyuorum: Part I. An annotated checklist of extant brachyuran crabs of the world. Raffles Bulletin of Zoology, Supplement 17: 1-286.

Reed S.K. \& Cumberlidge N. 2006. Taxonomy and biogeography of the freshwater crabs of Tanzania, East Africa (Brachyura: Potamoidea: Potamonautidae). Zootaxa 1262: 1-139.

Williams T.R. 1968. The taxonomy of the East African river-crabs and their association with the Simulium neavei complex. Transactions of the Royal Society of Tropical Medicine and Hygiene 62: 29-34. https://doi.org/10.1016/0035-9203(68)90027-8

Williams T.R. 1991. Freshwater crabs and Simulium neavei in East Africa. III. Morphological variation in Potamonautes loveni (Decapoda: Potamidae). Transactions of the Royal Society of Tropical Medicine and Hygiene 85: 181-188. https://doi.org/10.1080/00034983.1991.11812544

Williams T.R., Hynes H.B.N. \& Kershaw W.E. 1964. Freshwater crabs and Simulium neavei in East Africa. II. Further observations made during a second visit to East Africa in February-April 1962. Annals of Tropical Medicine and Parasitology 58: 159-168.

https://doi.org/10.1080/00034983.1964.11686226

Manuscript received: 23 February 2017

Manuscript accepted: 10 April 2017

Published on: 28 November 2017

Topic editor: Rudy Jocqué

Desk editor: Chloe Chester

Printed versions of all papers are also deposited in the libraries of the institutes that are members of the EJT consortium: Muséum national d'Histoire naturelle, Paris, France; Botanic Garden Meise, Belgium; Royal Museum for Central Africa, Tervuren, Belgium; Natural History Museum, London, United Kingdom; Royal Belgian Institute of Natural Sciences, Brussels, Belgium; Natural History Museum of Denmark, Copenhagen, Denmark; Naturalis Biodiversity Center, Leiden, the Netherlands; Museo Nacional de Ciencias Naturales-CSIC, Madrid, Spain; Real Jardín Botánico de Madrid CSIC, Spain. 